\title{
Applicability of Evaporation and Reverse Osmosis Techniques for Volume Reduction of Textile Mill Effluent
}

\author{
S. K. Rukade ${ }^{1}$, S. M. Bhosale ${ }^{2}$ \\ ${ }^{1}$ Department of Technology, Shivaji University, Kolhapur 416004 (India) \\ ${ }^{2}$ Assistant Professor, Department of Technology, Shivaji University, Kolhapur 416004 (India)
}

\begin{abstract}
Water is the most vital element known. More than $70 \%$ of the living material is made-up of water. Without it, life shall not be able to survive. It was said previously that water is ephemeral, that is, everlasting. However, the situation today is extremely dire. The Textile industry effluent is one of the most important biologically degradable wastewater streams, which have typical characteristics. So it need to be treated efficiently. Here we are applying evaporation and reverses osmosis technique for volume reduction of textile mill effluent.
\end{abstract}

Keywords: evaporation, reverse osmosis, volume reduction, effluent

\section{Introduction}

Currently, the Indian textile industry accounts for $9.0 \%$ of the global textile fibers production. India is the fifth largest man-made fiber producer in the world, after China, South Korea, Taiwan and Japan. Of the global production of around 24.0 million tons (MT) of man-made fiber, India produces around 1.5 MT. Thus, India's share of the world man-made fiber output is very low at around $7.0 \%$.The demand for polyester in the domestic market increased at the fast pace of over 15\%during the 1990s. Currently, polyester accounts for a significant $38 \%$ share of the country's total fiber consumption (for ultimate use in the domestic market, the share is even higher at more than $50 \%$ ). Further, the weaving industry, being weak, finds it difficult to export synthetic fiber based textile goods (the cotton and cotton-blend textiles and clothing are exported from India mainly on the strength of low raw cotton prices).

Man-made fibers are obtained by a manufacturing process, as distinct from materials which occur naturally in fibrous form. The term man-made fiber refers to the method offered production and not to the origin of the polymer material. The chemical compounds from which man-made fibers are produced are known as polymers. Man-made fibers are classified into organic and inorganic fibers. Organic fibers include fibers obtained from transformation of naturally occurring polymers and from synthetic polymers. The chemical composition, structure and properties of these fibers are significantly modified during manufacturing process. Examples of some of the man-made fibers include consumer products such as shirts, scarves, hosiery, home furnishings, etc., and industrial products such as cord, flameproof linings, drive belts, etc.

\section{Effluent from Textile Mills}

Textile wastewater includes a large variety of dyes and chemicals additions that make the environmental challenge for textile industry not only as liquid waste but also in its chemical composition. Most of the dyes are stable and has no effect of light or oxidizing agents. They are also not easily degradable by the conventional treatment methods. Removal of dyes from the effluent is major problem in most of textile industries. Dissolved solids contained in the industry effluents are also a critical parameter. Use of common salt and glauber salt etc. in processes directly increase total dissolved solids (TDS) level in the effluent. TDS are difficult to be treated with conventional treatment systems. Disposal of high TDS bearing effluents can lead to increase in TDS of ground water and surface water. Waste water of textiles is not free from metal contents. There are mainly two sources of metals. Firstly, the metals may come as impurity with the chemicals used during processing such as caustic soda, sodium carbonate and salts. For instance, caustic soda may contain mercury if produced using mercury cell processes. Secondly, the source of metal could be dyestuffs like metalized mordent dyes. The metal complex dyes are mostly based on chromium. Textile effluents are often contaminated with non-biodegradable organics termed as refractory materials. Detergents are typical example of such materials. The presence of these chemicals results in high chemical oxygen demand (COD) value of the effluent. Organic pollutants, which originate from organic compounds of dyestuffs, acids, sizing materials, enzymes, tallow etc. are also found in textile effluent, such impurities are reflected in the analysis of bio-chemical oxygen demand (BOD) and COD. These pollutants are controlled by use of biological treatment processes. In many textile units, particularly engaged in synthetic processing, low $\mathrm{BOD} / \mathrm{COD}$ ratio of effluent is observed which makes even biological treatment not a ready proposition. The wastewater of cotton based textile units is usually alkaline, whereas synthetic and woolen fabric processing generates acidic effluent.

\section{Effluent Treatment}

Textile wastewater includes a large variety of dyes and chemicals additions that make the environmental challenge for textile industry not only as liquid waste but also in its chemical composition (Venceslau et al., 1994). Main

\section{Volume 4 Issue 11, November 2015}




\section{International Journal of Science and Research (IJSR) \\ ISSN (Online): 2319-7064}

Index Copernicus Value (2013): 6.14 | Impact Factor (2014): 5.611

pollutants in textile wastewater came from dyeing and finishing processes. These processes require the input of a wide range of chemicals and dyestuffs, which generally are organic compounds of complex structure. Dyes contributed to overall toxicity at all process stages. Also dye baths could have high level of $\mathrm{BOD} / \mathrm{COD}$, colour, toxicity, surfactants, fibers and turbidity and may contain heavy metals (AEPA, 1998). Because all of them are not contained in the final product, became waste and cause disposal problems. Major pollutants in textile wastewaters are high suspended solids, chemical oxygen demand, heat, colour, acidity, and other soluble substances (Dae-Hee et al., 1999Venceslau et al., 1999.). Textile processing employs a variety of chemicals depending on the nature of the raw material and product (Aslam-et-al, 2004). Environmental problems of the textile industry are mainly caused by discharges of wastewater. Textile industries are major sources of these effluents (Ghoreishi and Haghighi, 2003) due to the nature of their operations, which requires high volume of water that eventually results in high wastewater generation. The untreated textile wastewater has a higher Biochemical Oxygen Demand (BOD), which can cause rapid depletion of dissolved oxygen if directly discharged into the surface water sources. The effluents with high levels of BOD and Chemical Oxygen Demand (COD) values are highly toxic to biological life. The high alkalinity and traces of chromium, which is employed in dyes, adversely affect the aquatic life and interfere with the biological treatment processes (Palamthodiet al., 2011).The quality of such effluent can be analyzed by their physico-chemical and biological analysis. Monitoring of the environmental parameters of the effluent would allow having, at any time, a precise idea on performance evaluation of ETP and if necessary, appropriate measures may be undertaken to prevent adverse impact on environment. The obtained results were very much useful in identification and rectification of operational and maintenance problems and it can be also utilized to establish methods for improved textile industry and plant waste minimization strategies.

\section{Methodology}

The present project involves lab scale experimentation of the raw textile mill effluent which will be obtained from the CETP situated in Ichalkaranji, Maharashtra. The effluent then subjected to both the units simultaneously, and batch wise experimentation were carried out to observe the process. The samples were collected separately and analyzed for the different parameters like $\mathrm{pH}$, TDS, Hardness, Chlorides and COD using the methods prescribed in the Standard Methods for Water and Wastewater Analysis, $20^{\text {th }}$ Edition by American Public Health Association (APHA).

\subsection{Materials and Methods}

The lab scale apparatus that was used as the Evaporation unit is a modified VA Distillation apparatus. The flow chart of this apparatus is as given in the below figure.

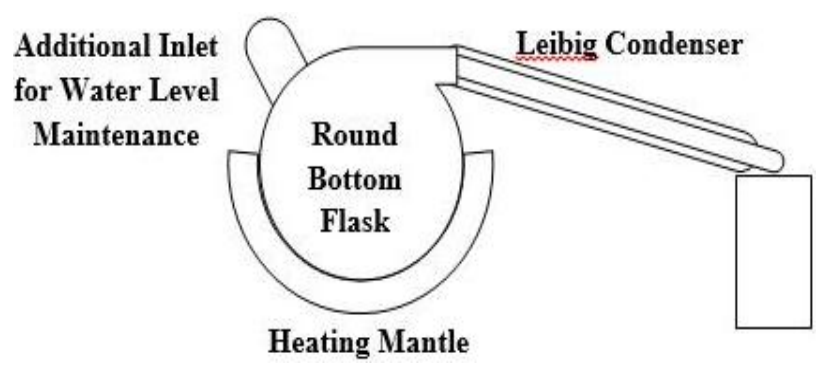

\section{Distillation unit}

\section{Evaporation unit}

\subsection{Lab scale Reverse osmosis unit}

The Lab scale reverse osmosis unit which was used in the experiment was a locally assembled household RO purifier. Modifications were made in the pumping arrangement to suit the pressure requirement for the textile effluent. The apparatus was be provided with a pre - treatment to remove any type of suspended particulates in the water which may otherwise case chocking of the RO Membranes. The process flow chart of the Reverse osmosis system which was utilized is as given below.

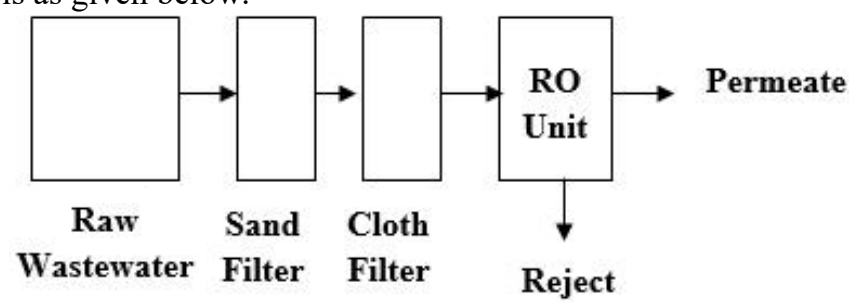

The analyses were carried out by at the CETP Laboratory according to the standard methods prescribed by APHA.

\section{Results and discussion}

Textile effluent generation is a very crucial issue when we consider the clusters of these industries situated all over the country. Further, the treatments in place are carelessly left to contracted personnel who may not have the requisite qualifications or experience to handle the wastewater. Thus, generation of an untapped and highly polluted potential resource occurs. It is therefore necessary to evaluate the feasibility of using different techniques for the proper management of this waste which would not only reduce the pollution level, but also, make available water for recycling in the process.

\subsection{Characterization of Textile Effluent}

The textile effluent is generated mainly from the wet processes of the textile industry. The main characteristics of this wastewater are color, organic load, total dissolved solids, and odor. These characteristics make it unfit for disposal as it is and hence, proper treatment measures need to be applied. However, the capital cost incurred in the process is very high and small to medium scale textile industries therefore, are unable to establish these schemes, and therefore, dispose the water to a Common Effluent Treatment Plant (CETP) by paying certain treatment costs. The detailed characteristics of textile effluent are as given below. 
International Journal of Science and Research (IJSR)

ISSN (Online): 2319-7064

Index Copernicus Value (2013): 6.14 | Impact Factor (2014): 5.611

\begin{tabular}{|c|c|c|}
\hline Parameter & Inlet & Outlet \\
\hline $\mathrm{pH}$ & $7.0-11.0$ & $6.5-8.5$ \\
\hline $\mathrm{COD}(\mathrm{mg} / \mathrm{L})$ & $2000-3000$ & $<250$ \\
\hline BOD3 at $27^{\circ} \mathrm{c}(\mathrm{mg} / \mathrm{L})$ & $800-1000$ & $<100$ \\
\hline Oil and grease $(\mathrm{mg} / \mathrm{L})$ & $20-50$ & $<10$ \\
\hline Total Suspended $(\mathrm{mg} / \mathrm{L})$ & $100-500$ & $<100$ \\
\hline Total Dissolved $(\mathrm{mg} / \mathrm{L})$ & $2000-3000$ & $<2100$ \\
\hline Dissolved Oxygen $(\mathrm{mg} / \mathrm{L})$ & $0-1$ & $>2$ \\
\hline
\end{tabular}

\subsection{Evaporation for Volume Reduction}

1) INLET Sample

2) Concentrate (Conc.) Sample (Initial Sample Volume $500 \mathrm{ml}$ )

3) Concentrate at $30 \%$ Reduction $(350 \mathrm{ml}$ of $500 \mathrm{ml})$

4) Concentrate at $60 \%$ Reduction $(200 \mathrm{ml}$ of $500 \mathrm{ml})$

5) Concentrate at $75 \%$ Reduction. $(125 \mathrm{ml}$ of $500 \mathrm{ml})$

The efficiency was kept at $75 \%$ maximum since, as per the RO manufacturers, the efficiency of an RO system is between $65-75 \%$ on a practical scale.

1) Condensate (Cond.) Sample

2) Condensate at $30 \%$ Reduction $(150 \mathrm{ml}$ of $500 \mathrm{ml})$

3) Condensate at $60 \%$ Reduction $(300 \mathrm{ml}$ of $500 \mathrm{ml})$

4) Condensate at $75 \%$ Reduction $(375 \mathrm{ml}$ of $500 \mathrm{ml})$

\subsection{COD}

The Chemical Oxygen Demand test is widely used as a means of measuring the organic strength of domestic and industrial wastes. This test allows measurement of a waste in terms of the total quantity of oxygen required for oxidation to carbon dioxide and water. It is based on the fact that all organic compounds, with a few exceptions, can be oxidized by the action of strong oxidizing agents under acidic conditions. The analysis in the present case demonstrated that on concentration of the textile effluent, the COD of the Concentrate increased significantly, while the COD of the condensate was considerably low.

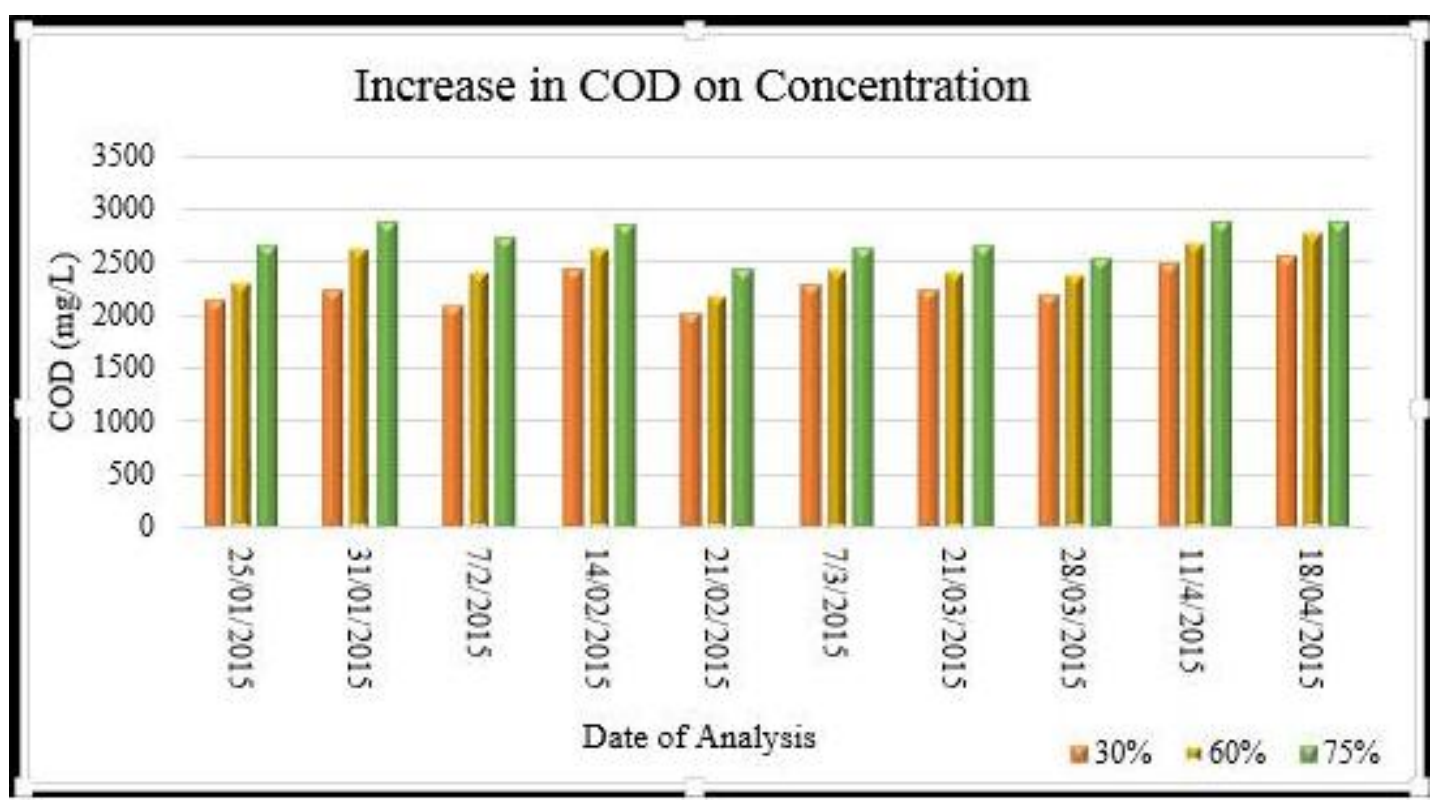

Variations in COD on Concentration

\section{$5.4 \mathrm{pH}$}

The $\mathrm{pH}$ of the concentrate and condensates demonstrated an interesting correlation between the concentration process and the characteristics change. On concentration, the $\mathrm{pH}$ of the concentrate increased towards the alkaline range, while the $\mathrm{pH}$ of the condensate reduced to the standard optimum range, inclining towards the alkaline phase of the $\mathrm{pH}$ range. This inclination can be due to the organic entrainments from the concentrate.

\subsection{Alkalinity}

In the present study, it was observed that alkalinity was not significantly crucial in the process assessment from separation perspective. This is because, as is clear from the figures, majority portion of the alkalinity of the effluent remains in the Concentrate portion. Further, the alkalinity in the condensate can be due to the entrained volatile organics only, since the salts portion of the effluent again remained concentrated in the concentrate.

\subsection{Volume reduction by RO}

For the present study, a pre-fabricated RO System provided by $\mathrm{M} / \mathrm{s}$. Sai Enterprises Ltd., Sangli was utilized for the study. However, due to the limitations of the equipment membranes, in order to meet the economic and process suitability, the study was carried out for 3 samples only. The RO System was provided for the study free of cost in order to encourage the research study.

According to the manufacturer, Mr. Mandar Gogate (Owner), the domestic RO plant which was being used for the study operates at Reject to Permeate Ratio of $50: 50$, and the efficiency of treatment varies between $70-75 \%$ average. Though a higher efficiency could be achieved, the Reject to Permeate Ratio may incline towards higher rejection which may cause significant impact on project feasibility. 


\section{International Journal of Science and Research (IJSR) \\ ISSN (Online): 2319-7064}

Index Copernicus Value (2013): 6.14 | Impact Factor (2014): 5.611

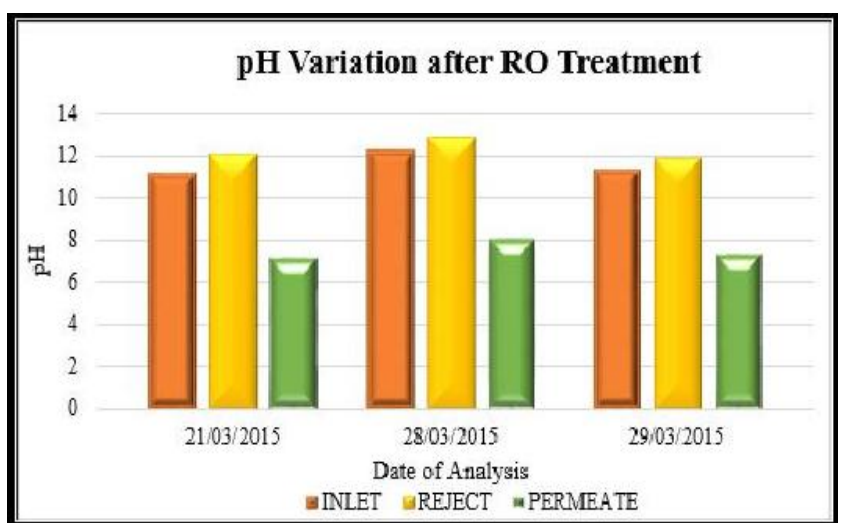

COD Variation after RO Treatment

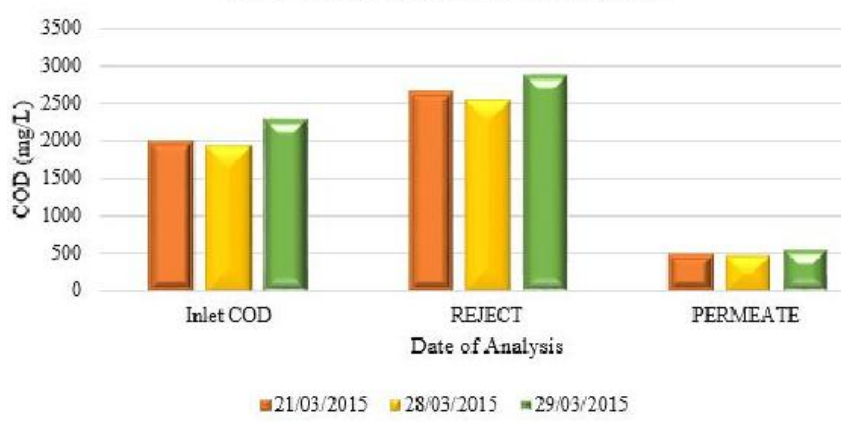

\section{Conclusion}

The Chemical Oxygen Demand test is widely used as a means of measuring the organic strength of domestic and industrial wastes. This test allows measurement of a waste in terms of the total quantity of oxygen required for oxidation to carbon dioxide and water. It is based on the fact that all organic compounds, with a few exceptions, can be oxidized by the action of strong oxidizing agents under acidic conditions. The analysis in the present case demonstrated that on concentration of the textile effluent, the COD of the Concentrate increased significantly, while the COD of the condensate was considerably low. COD inlet 2000 and condensate $50-250 \mathrm{mg} / \mathrm{l}$.

The $\mathrm{pH}$ of the concentrate and condensates demonstrated an interesting correlation between the concentration process and the characteristics change. On concentration, the $\mathrm{pH}$ of the concentrate increased towards the alkaline range, while the $\mathrm{pH}$ of the condensate reduced to the standard optimum range, inclining towards the alkaline phase of the $\mathrm{pH}$ range. This inclination can be due to the organic entrainments from the concentrate. PH of inlet is $12-14$ can be reduced up to 8 .

It can be applicable for field scale. RO technique is costly than MEE system. Operation and maintenance of MEE is lesser than RO. There are less moving parts in MEE than RO. Alkalinity and chloride content increases as percentage of concentration of evaporation increases.

\section{References}

[1] Praveen Sharma, Lakhvinder Singh and Jyoti Mehta "cod reduction and colour removal of simulated textile mill wastewater by mixed bacterial consortium", Rasayan J. Chem. Vol.3, No.4 (2010), ISSN: 09741496, 731-735.
[2] Dr. B. Sengupta, Member Secretary, a Handbook on "Central Pollution Control Board Ministry Of Environment and Forests" CPCB, 2007,200 Copies.

[3] SachinkumarSalakki, M A Lourdu Antony Raj, Jagadish $\mathrm{H}$ Patil, VikasShetty, "Improving the Efficiency of Multiple Effect Evaporator to Treat Effluent from aPharmaceutical Industry",International Journal of Innovative Research in Science,Engineering and Technology, ISSN: 2319-8753, Vol. 3, Issue 7, July 2014.

[4] NorazziziNordin, SitiFathritaMohd Amir, Riyanto, Mohamed Rozali Othman,"Textile Industries Wastewater Treatment by Electrochemical Oxidation Technique Using Metal Plate",Int. J. Electrochem. Sci., 8 (2013) 11403 - 11415.

[5] Prashant Mehta, "Treating textile effluents by coagulation - flocculation method using different dosing compositions", Advances in Applied Science Research, ISSN: 0976-8610 CODEN (USA): AASRFC, 2012, 3 (4):2514-2517.

[6] B. Ramesh Babu, A.K. Parande, S. Raghu, and T. Prem Kumar, "Cotton Textile Processing: Waste Generation and Effluent Treatment",TheJournal of Cotton Science 11, (2007), 141-153.

[7] M.A. Darwish," Fundamentals Of Multiple Effect Evaporation",Encyclopedia of Desalination and Water Resources (DESWARE), Thermal Desalination Processes - Vol. II.

[8] S.EswaramoorthI," Designing Zero Discharge System For A Textile Waste Water Treatment Plant",www.ecpconsulting.in 2010.

[9] A Case study on "Dyeing, Bleaching and Integrated Textile Processing Sector", www.ecacwb.org, 2010.

[10] Davinder Singh, Vasundara Singh, Agnihotri. A.K, “ Study of textile effluent in and around Ludhiana district in Punjab, India",International Journal Of Environmental Sciences, Volume 3, No 4, ISSN 0976 $4402,2013$.

[11]Vinodha S, John Thomas, Robbie Varghese, Jegathambal P "Decolorization of red CLB dye using membrane bioreactor", International Journal of Environmental Sciences, Volume 3, No 5, ISSN 09764402, 2013.

[12] V. B. Upadhye and Sunil S. Joshi, "Advances In Wastewater Treatment- A Review",International Journal of Chemical Sciences and Applications, ISSN 0976-2590, Online ISSN 2278 - 6015, Vol 3, Issue 2, 2012, pp 264-268.

[13] Sunil k. Sharma, Neetu Sharma, Amrita Shrivastava, "Optimization of Biological Oxygen Demand Reduction from Textile Effluent by Oxidation", IOSR Journal Of Environmental Science, Toxicology And Food Technology (IOSR-JESTFT) ,e-ISSN: 2319-2402,pISSN: 2319-2399. Volume 5, Issue 3 (Jul. - Aug. 2013), PP 44-50.

[14] B. Ramesh Babu, A.K. Parande, S. Raghu, and T. Prem Kumar, "Cotton Textile Processing: Waste Generation and Effluent Treatment",TheJournal of Cotton Science 11, 2007, 141-153.

[15] Desai P. A. and Kore V. S., "Performance Evaluation of Effluent Treatment Plant for Textile Industry in Kolhapur of Maharashtra",Universal Journal of Environmental Research and Technology,ISSN 2249 


\section{International Journal of Science and Research (IJSR) \\ ISSN (Online): 2319-7064}

Index Copernicus Value (2013): 6.14 | Impact Factor (2014): 5.611

0256, Volume 1, Issue 4,2011, 560-565,

[16] Sumitkumar Patel, "Performance Evaluation of Effluent Treatment Plant of Textile Wet Processing Industry: A Case Study of Narol Textile Cluster,Ahmwdabad,Gujarat,International Journal of Engineering Science and Technology", Vol 2, 2013,pp 290-296. 